\title{
Soft Power: A Critical Factor for the Effectiveness and Development of a School
}

\author{
Hui-Min Ko \\ Department of Technology Application and Human Resource Development \\ National Taiwan University, Taiwan
}

\begin{abstract}
This research aims to explore the contents of a school's soft power, including culture, strategy, leadership, learning, marketing and innovation. Managing soft power not only is critical for a school's development, but also should be regarded as a indispensible asset of schools. The measures for a school to establish its soft power are: establishing core values, shaping a learning school, emphasizing on knowledge management, innovating, and introducing a more adaptive marketing strategy. A school could become more perspective and sustainable through soft power, and thus be able to deal with a fast-changing educational environment and meet practical requirements.
\end{abstract}

Keywords: soft power, organizational culture, learning school, marketing strategy.

\section{Introduction}

Prof. Joseph S. Nye of Harvard University proposed his idea of "soft power" in 2004. Soft power, in accordance with Nye, is an ability to achieve goal through its own attraction rather than threats or seduction, and such an attraction comes from a country's culture, political values, and diplomatic policies. Since then, global research and application of soft power began; meanwhile, most countries also vigorously enhance their own soft power and regard it as an important strategic factor for domestic and international development. Currently, researches on and applications of soft power are so popular that soft power is discussed worldwide. Even most governments, enterprises and schools all have an idea to establish their own soft power in order to meet today's challenges. In the light of that schools play an important role in matters such as education and academic exchange, and that the establishment and management of soft power in the mean time are critical for a school's development, this research aims to explore the contents of soft power and establish some measures for soft power to improve a school's effectiveness and competitiveness, and thus the school's goal of sustainable management could be achieved.

\section{The Contents of School Soft Power}

The comprehensive power of a school includes hard power and soft power. Hard power is apparent and easy to evaluate, which includes buildings, facilities, teachers and 
funds. Soft power, on the other hand, is less obvious and more difficult to evaluate, which includes visions, spirits, culture, system, management, image and reputation. Internally, the soft power of a school represents a kind of cultural power, and, externally, an attraction and influence. It is the sum of a school's cultural power, strategic power, leadership power, learning power, innovation power, and marketing power (Chang, Ming-hui 2009 ).

\subsection{Cultural Power}

School culture is a school system composed by various codes, values, and meanings, which is shared and utilized by all the school members; it is also a legacy of ideology, including codes, systems, values, beliefs, rituals, and traditions, which could be divided into faculty culture, student culture, executive culture, community culture, material culture and spiritual culture (Zhang, Duo-yan, 2007). The power of these cultures is intangible but unlimited. They could not only enrich educational system, but also work in areas that system is unable to touch, and that is why they keep a school alive. The development of school culture could increase the performance of the school members, and help a school become more effective ( Tsai, Chin-hsiong, 2000 ).

\subsection{Strategic Power}

Strategy is a form of integrating and coordinating resource allocation. In terms of an uncertain future, it is also a process analyzes the quality of internal and external resources, adapts the change of overall environment, and proposes the most adaptive way to achieve the goal of an organization ( Tang, Chih-ming, 2009). A school's strategic power, therefore, is a set of plans that are determined in accordance with that school's goals, characteristics, and its own conditions, and aims to achieve the goal of sustainable operation. This set of plans defines a school's area of operation; it is also the blue print, procedure and measure to achieve goals of a school (Hax, 1991). An excellent strategic power of operation could outline the future development. A school head should have an overview of the environment and adopt proper operation strategy so as to survive and excellence, especially during a time when resources are limited and competition is fierce.

\subsection{Leadership Power}

Leadership is an art to influence people and stimulate them to complete missions and improve organizational behavior through providing motives, directions and goals, as well as utilizing personal charm, effective management and encouragement (Xie, Yu-lin, 2008). Leadership is to help a team to achieve its goals, maintain its integrity, and encourage it members (Wu, Ching-shan, 2006). The quality of leadership influences not only an organization's performances, atmosphere and future development, but also how much of its members' need could be met. A school leader's leadership style would have a profound influence on the performance and development of his or her school, and the satisfactory degree and performances of school members. Furthermore, the leadership style is the major power to develop the school's soft power. 


\subsection{Learning Power}

The purpose of organizational learning is to endow an organization with learning power, making its members have a core value of being eager to learn, personal mastery and willing to change and innovate; it also aims to commence organizational transformation, and encourage members in an organization to examine themselves, learn from each other, ponder problems and take actions to solve them (Xie, Hui-juan, 2004). School learning activities are the extension of organization learning. A school's learning power could improve the quality of its members, develop a team learning environment, and promote the value of teamwork. This fact has a significant influence on a school's integration, innovation and organizational culture development. This fact also could encourage a school to learn and progress. Learning power, one of a schools' soft powers, emphasizes the fact that people could learn whenever and wherever, and that everyone is a learner. Such a learning system includes the learning activities of the student, the faculty and leader (Zhang, Ming-hui, 2005).

\subsection{Marketing Power}

School marketing is a concept that regards school as a market, and applies the idea of marketing to the daily life in a school. Through activities such as analysis, planning and execution, this concept aims to make faculty, community, parents, and general public understand a school's visions, teacher's quality and curriculum. A successful school marketing includes enhancing prestige, increasing competitiveness, solving recruiting difficulty, gaining more external resources, and effectively reaching an internal consensus (Xu, Xiao-jun, 2011). Measures for school marketing include internal marketing, external marketing and interactive marketing (Wu, Ching-shan, 2005).

\subsection{Innovation Power}

Innovation has the meanings of "make change" or "introduce new things" (Wu, Ching-shan, 2005). School innovation is "a process that adapts creative ideas and translates them into services, products, or means that deal with things in a school environment in order to develop a school's characteristics, improve its effectiveness, and thus to achieve the goal of education" (Wu, Ching-shan, 2003). The major functions of innovation are to display educational dynamics and creativities, enrich educational contents and activities, ensure schools' survival and development, and improve and excellence education quality. Innovation includes the change of ideas, technologies, services, operational procedures, activities and environments (Wu, Ching-shan, 2003).

\section{Ways to Develop School Soft Power}

\subsection{Establishing Core Values}

A school's core value comes from its history, culture and characteristics, as well as the spirit of the times. The core value is the stem and soul of school culture. It is also a prerequisite and foundation of a school's soft power. It reflects the common value and 
vision of the faculty and student, and represents a school's goals and visions. Based on school's characteristics and needs for development, the principles to establish a core value are: reviewing its own history; analyzing current situation; widely inquiring comments and suggestions from students, faculty, and people who concern the school; extracting merits from the school's tradition; forming a core value with profound and unique connotation; and making this value become a common belief and principle for each and every school member.

\subsection{Shaping a Learning School}

The idea of learning school develops from learning organization. The concept of learning organization is based on Peter M. Senge's "The Fifth Discipline", which is composed by system thinking, improving mental models, personal mastery, building shared vision and team learning. To thoroughly understand the fifth discipline is the foundation for the establishment of learning organization.

In addition to integrate the fifth discipline into school's learning strategy and major task, I feel that the essence of the idea of learning school is "learning". All the school head, faculty, student and parents of the community should be the main body of a learning school. The ways to form a learning school are: setting learning goals, transforming school leaders into learning ones, developing the student's self-directed learning ability, encouragement and rewarding.

\subsection{High Quality School Leadership}

A school leader should have characteristics that could lead, improve, and excel his or her school, and should also have a respectable personality to win respect from school members and make them follow his or her leadership wholeheartedly. In addition, one should notice that although there are various leadership theories, research results show that no one single type of leadership could be applied to everyone and everywhere. A leader should be able to adjust his or her leadership in accordance with circumstance. Therefore, a school head should choose an effective way to lead in accordance with the characteristics of faculty, student and environment so as to meet school's requirements, and to lead the school effectively and efficiently(Wu, Ching-shan, 2006).

\subsection{Emphasizing Knowledge Management}

In accordance with Zhang, Ji-cheng (2006), knowledge management is "a knowledge activity that promotes the accumulation, spread, sharing, creation, value-adding or efficiency of knowledge in an organization through development and effective utilization of knowledge by using of the tool of information management". The knowledge management in a school, therefore, is to establish an effective knowledge management system in order that the knowledge in school organization could be effectively created, circulated and added more values, and thus that more innovative professional knowledge of education could be produced constantly. In order to improve school knowledge management, there should be support and promotion from the 
leader, specially-assigned persons to be in charge of knowledge management matters, and a knowledge management strategy that encourages organization members to create and contribute special knowledge, and rewards anyone who do so. Furthermore, a knowledge base, data base and information circulation system should be established in order to transform any useful knowledge into information, systemize the knowledge, make the knowledge more accessible, and constantly update knowledge. Meanwhile, knowledge should also be permanently stored in computer software so that users could access to and utilize knowledge more efficiently and that the experience and knowledge of a school could be shared on information platform.

\subsection{A More Adaptive School Marketing Strategy}

A school should establish a service- and customer-centered culture. Under this culture, a school could more concern about customer while making decision, teaching and holding an activity. Under this culture, a school could improve its service quality to win the customer's heart and acquire more recognition and support. Furthermore, in prior to marketing itself, a school should have several discussions and brainstorming on matters such as upper guidance, school environment, internal and external resources, teacher's specialty, student's need, and expectation from parents, in order to reach a consensus between school members. Thus, school characteristics could be developed, reputation could be established, and recognition and support from the public could be gained.

\subsection{Innovative Operation}

Innovative operation demonstrates that fact that school operation concept is changing and school culture is reforming. The sustainable development of innovative operation is based on learning organization. School leaders should have an innovative mind set and shape a new organizational culture, atmosphere, environment and condition in order to establish a decision-making model composed by brainstorming, mutual discussion, and tolerance. They should be able to encourage school members to actively participate in school operation, work as a team, brainstorm, discuss mutually, and tolerant dissenting views so as to improve competitive edge of the school (Zhang, Ming-hui, 2009). The following measures could be used to promote innovative operation: creating a special team to promote innovative operation, encouraging cooperation and sharing among school members, learning from other schools, establishing a platform for innovation, providing adequate resources, and rewarding those who make significant contributions to innovative operation.

\section{Conclusion}

With the trend of globalization and commercialization of education, schools of all levels are facing a fierce competition and serious challenge. The establishment and 
development of soft power are critical for a school to survive and excel. Developing soft power is a lengthy and accumulative process that requires wisdom. The six components of school soft power proposed in this research include: cultural power, strategic power, leadership power, learning power, marketing power, and innovation power. The six soft powers that are interconnected and complemented each other could cohere, stabilize, influence, innovate, and develop a school organization. One who would like to bring soft power into full play should: establish profound and unique core values and translate these values into a common belief and code for all the members in the school; create a learning environment to promote group learning, encourage school members to work coherently and induce organization teamwork; develop high quality leadership to boost morale and improve organization efficiency; emphasize knowledge management in order to share and learn knowledge and experience; have the courage to change and innovate to fill the school with energy, So as to make sure a more forward looking, sustainable, adaptive, and responsive educational environment and requirements.

\section{References}

1. Cai, J.-X.: Leadership Transformation and School Effectiveness, pp. 76-77. National Taiwan Normal University Press, Taipei (2000)

2. Chang, M.-H.: An Research on School Operation and Management: Vision, Integration and Innovation, pp. 85-89. Pro-Ed Publishing Company, Taipei (2005)

3. Chang, M.-H.: The Soft Power of School Operation. Journal of Educational Research (188), 27-35 (2009)

4. Hax, A.C.: Redefining the Concept of Strategy and the Strategy Formation Process. Engineering Management Review 19(1), 19-24 (1991)

5. Nye Jr., J.S.: Soft Power, The Means to Success in World Politics, p. 25. Public Affairs, New York (2004)

6. Senge, P.M.: The Fifth Discipline: The Art and Practice of the Learning Organization, Chinese version, trans. by Jin-lun Guo, pp. 10-17. Military History and Translation Office, Ministry of National Defense, Taipei (2002)

7. Tang, Z.-M.: School Strategic Management. Friends of National Education 60(4), 1-2 (2009)

8. Xie, H.-J.: Planning and Practice of a Learning School. Inservice Education Bulliten 21(1), $13(2004)$

9. Xie, Y.-L.: The: New Area of Military in Economy-Based Knowledge Era: Military-Based Knowledge. National Defense Journal 23(6), 70-71 (2008)

10. Xie, Y.-L.: On the Communication Art of Strategic Leadership. National Defense Journal 23(2), 93 (2008)

11. Wu, Z.-L.: The Marketing Strategy for School Management. Educational Information and Research (53), 61-69 (March 2004)

12. Wu, C.-S.: School Administration, pp. 165-196. Psycological Publishing Co., Taipei (2006)

13. Wu, C.-S.: The Ehtablishment of a School's New Management Strategy. Secondary Education 56(3), 2-26 (2005) 
14. Wu, C.-S.: Innovative Managment. Educational Information and Research (53), 134-135 (July 2003)

15. Xu, X.-J.: The Application of School Mketing Srategy on Public Relations of a School. Journal of National Taichung University: Education 25(1), 121-137 (2011)

16. Zhang, D.-Y.: Introduction to Education, pp. 66-67. National Open University, Taipei (2007)

17. Zhang, J.-C.: Management and Innovation of Knowledge, p. 67. Chuan Hua Science \& Technology Book Co., Taipei (2004) 